\title{
The Bugis-Makassar Women Imagery in the Lontaraq Manuscripts
}

\author{
Husnul Fahimah Ilyas \\ \{husnullitbang@gmail.com\} \\ Religious Research and Development, Ministry of Religious Affairs Makassar, Indonesia \\ Universitas Hasanuddin, Indonesia
}

\begin{abstract}
The Bugis-Makassar women imagery in domestic and public that was reflected through the Lontaraq manuscript. The background of this review is how the imagery and the role of Bugis-Makassar Women in Lontaraq Manuscript. The method of descriptivequalitative. This review collected data from the manuscript which have been transliterated and translated including Lontaraq Bugis-Makassar as well as manuscript related to Bugis-Makassar women. In the Lontaraq manuscript, we found that the position of the women as Goddess of Life (Dewi Sang Hyang Seri), the most respected figure who maintain the welfare of the human on earth. Moreover, Bugis-Makassar women, uphold religion values, are imaged as loyal, and submissive women, like the figures called. On the other hand, women are imaged as religion experts and guardians. Besides, women are also figured as intellectuals, brave men and fighter who have a high spirit to struggle that is depicted in the figure of Colli Pujie.
\end{abstract}

Keywords: Manuscript, Women, Figure

\section{Introduction}

Some discussions upon gender these current days are massively voiced out by both Western and Indonesian activists. They are demanding the equality between men and women. This has arisen due to the status carried by someone. Such status in this case is an assessment of how important a person is viewed within the family and the society. The low status of women has led to discrimination, resulting in some bad treatments which occurred in different forms.

This movement is not only restricted to socio-cultural issues, but also widening to the religious doctrine which is considered significantly played a role in creating social construction related to the relations between men and women. In Indonesia, for instance, the majority are Muslim, who dominantly rely on the views of Islamic scholars (hereafter ulama) in terms of religion, while women are rarely categorized as religious experts ulama [1]. It should be noted that the concept of ulama shows in personal capacity not gender. Relating to this, not many books have been published that try to change our paradigm, and further provide enlightenment about the concept of female scholars. However, some Indonesian female scholars in fact function as activists in the fields of education, thinkers, study pioneers, community developers, political activists in Islamic parties, religious social fighters, artists, preachers, tarekat figures, and Islamic boarding school pioneers [2]. 
This gender equality provides a fairly comprehensive debate upon the position of women. Some conclude that women have been given such freedom to act and move in the public. Thus, it is not surprising that the title of heroes, intellectuals, academicians, and even scholarly figures can be linked to women. This somewhat in contrast to the reading material offered. The question then raises, how about the issue at the local level, will we get strong women to serve as guardians, sufis, warriors, intellectuals, political figures and so on?

The basic assumption of this question can be examined through the lontaraq manuscripts found among Buginese-Makassar tribe, as one of the empirical evidences and as a historical source of the important role of women, who can become public figures both in the public and domestic area, especially in establishing the culture.

\section{Methodology}

This existing research was a descriptive study. The method used in this study was a text approach written in historical Buginese and Makassarese manuscripts, which have been found over Buginese and Makassarese ethnics. The contents of the text were related to the roles of Buginese-Makassarese women as the object of study. In addition, texts were also used in the inscriptions describing a woman's character, as well as manuscripts that have been transliterated and translated by several editors.

The manuscripts and the results of editing used as study material were institutional and personal collections. These data were primary data, while secondary data were from books, papers, journals, and other materials related to the research topic.

The texts in the Buginese-Makassarese language contained in the manuscript were translated, and then presented in the form of a simple narrative. In addition, the results of the edits were rethinked as the reading results of researchers to describe the figure of ancient Buginese-Makassarese women as real proof, that Buginese-Makassarese women since ancient times have held an important position in the public sphere.

\section{Findings and Discussion}

Some of the stories told about the role of Meong Palo whose employer was not happy with her. She was always being tortured and mistreated repeatedly until Sang Hyang Seri decided to take adventure with Meong Palo. Their journey started from Soppeng to Maiwa Enrekang. Once she arrived, she only ate rice and fish bones, and was tortured repeatedly until she was dumped on the ground and hunted by dogs. The pestle, wood, iron, and bamboo constantly hit Meong Palo. Meong Palo finally ran to the rakiang on a pile of rice bowing her head right in front of I Tunek Datu Sang Hyang seri. Her employer torture unceasingly, until disrupting the sound sleep of Sang Hyang Seri. I Tunek ibah saw Meong Palo and felt that the safety of the rice was not guaranteed. Here cats became the only hope to keep Sang Hyang Seri along with other rice flocks, away from the rats and pecking chickens so they did not scatter. However, Meong Palo could not be expected. So Datu Sang Hyang Seri invited the group of rice and Meong Palo going to the Maiwa mangkubumi's house. Sang Hyang Seri found children eating, their rice scattered without being picked up by their mother. This behavior was so hated by Sang Hyang Seri because he did not appreciate the results of plants. 
So, she left Maiwa village adventuring to over Soppeng-Pattojo-Mario up to Lakemmek. When she arrived there, she found sorghums, corns, and all the staples of food outside the village which suffered greatly. The Lakemme's actions were despicable, cursing her children, ignoring her family, and always disagreeing with each other. Sang Hyang Seri's journey had arrived at Soppeng, but there was no peace and tranquility. Other words to say, people were fighting quarreling just before sunset. In the house located in the east, no one lighted on the lamp as night time was coming, the plate did not contain water and the kitchen did not steaming. Such treatments were hated by Sang Hyang Seri because of the laziness of the villagers as there was no life. Sang Hyang Seri and her entourage left Soppeng heading to Mangkoso. During the way, Wettu stopped by for a while to rest and calm her soul, yet she did not get peace.

Datu Sang Hyang Seri was not feeling peace in Wettu village, thus she continued her journey and finally arrived at Lisu. The environment in Lisu was very crowded to welcome the seed traditional ceremony but the served rice was not enough. Consequently, Matoa Lisu's family murmured out while swearing, that the distributed rice did not get any results even though Matoa money had been spent out to take care of all the plant seeds. Next to the Matoa's house, Lisu, a husband-and-wife couple fought and there was no peace any longer. Datu Sang Hyang Seri's entourage left Lisu heading to Barru with an expectation to get the dream. When she arrived at Barru, Sang Hyang Seri got a speaker family member speaking politely, then immediately lifted up to the house and spread the fragrance. The wife of the speaker took water in the kettle and immediately washed Datu Sang Hyang Seri's feet while worshiping her. Sorghum and all rice and Meong Palo had been provided with a special place [3]. After that, a welcoming ceremony was held served by siri.

Sang Hyang Seri was highly respected, her advice and appreciation towards natural products were imprinted on kings. Among them were Puang Rimaggalatung (The King of Wajo) carried out such tradition when the rice planting season had arrived, entertaining his people while giving the message: "do not either fight with one another, and or with the whole house". After the party, Puang Rimaggalatung asked for blessing from the Gods to start planting the rice seeds. During planting the seeds, Puang Rimaggalatung slept alone performing rituals and pray to Sang Hyang Seri, and beg for forgiveness to the Gods for all the mistakes made by his people. Also, after the harvesting was finished, Puang Rimaggalatung set a party and served a buffalo in the form of sacrifice for the gratitude of the harvest that had been obtained by his people. This was expected that Sang Hyang Sri stayed living in his place for the welfare of the people of Wajo [4].

Besides Sang Hyang Seri, there were also such other figures such as Sitti Saerah, Rabiatul Adawiyah, and Darma Tasiya. These three female figures had played a greater role upon religious matters. As told in lontaraq, there lived a woman named Sitti Saerah who lived in a village together with her husband namely Sultan Haruna (Sekh Hulere) [5], they lived in harmony. Both of them obeyed the commands of Allah almighty and His Messenger. All Sitti Saerah's activities were carried out based on permission and blessing from her husband. However, Sitti Saerah along the way disobeyed the rule when Sekh Hulere, performed Friday prayers at the mosque. Sitti Saerah was left alone. By the grace of God, she was shown Kausar water in front of her house. Suddenly Sitti Saerah also came down from her house, and then took a bath in the river Kausar with the angels, without asking for permission to her husband first. After Sekh Hulere returned from Friday, did not see his wife anymore.

For the first time, Sitti Saerah left home. Without saying goodbye to her husband, Sitti Saerah was then divorced by her husband. As the main reason of divorce, Sitti Saerah was no 
longer afraid to God. She had no shame. Since then, Sitti Saerah was not allowed to live with Sekh Hulere, and she had to go find another place to live.

The departure of Sitti Saerah from her husband did not necessarily mean forgetting her husband. Such habit of praying for her husband after she prayed was still being carried out, because of the fear of being disobedient to her husband, disobedient to Allah and His Messenger. This obedience had an impact on the friendlies of Sitti Saerah, her prayers were answered. Sekh Hulere went to the forest to picking up his wife to settle back in the village. Many people learned and became his loyal students, including Sekh Abdoleng who was very active in learning process. The knowledge taught was about the nature revealed by Allah to his servants was 20 .

Not so unlike between the story of Siiti Saerah and that of Darma Tasiya, a wife who obeyed her husband, also experienced the same life challenge. In the test their prayers were always answered. This also happened to some female Sufism figures, such as Rabiatul Adawiyah. Her story had been told and written in a Bugis-Makassar lontaraq with the Buginese-Makassaris cultural background.

Besides the description of the female Sufi who was introduced in various stories. There was a Buginese woman with particular character named Colliq Pujie. She was a smart Buginese woman, a scientist, a historian, and a writer [6]. This skill was proven by her ability to copy La Galigo for about 12 volumes which book is now kept in the Netherlands. The history of copying La Galigo was carried out by Colliq Pujie at the request of Matthes. This became a concrete proof of the greatness of Colliq Pujie until now. Such greatest work has been widely become a source of reading and study from various nations over the world [7].

The maturity of Colliq Pujie's mind led her to explore Buginese literature and culture well. La Galigo's story was written or re-edited by Colliq Pujie for about 12 volumes were: (1) telling about Batara Guru who was descended from the sky and We Nyiliq Timo rose up from Uri Liu, until the birth and raising of Bata Lattuq; (2) Sawerigading traveled to over regions of Luwu and outside Luwu such as Tompoqtikka, Wadeng, and Maloku; (3) Renewal of the grave of La Urumpessi and We 'Padauleng. After that, Sawerigading sailed to Bima and various strange places like the center of the earth, the spirit world lying in the underworld; (4) Next journey was to places that had never been visited before. Upon his return in Luwu to investigate his return in Luwu to investigate his twin brother, and after meeting he directly fell in love. Walenreng tree was then cut down used as a boat to sail to China [8].

Colliq Pujie's essay or other copy, namely: Hikayat Bayan Budiman; The history of ancient Tanete/La Toa; Sureq Baweng. Colliq Pujie was not only a writer of high-value literary works that only mastered the ancient Buginese language, but she also mastered other languages. Her Intelligence and mastery of language, culture, literature, and history had led the creativity Colliq Pujie in creating words of bilang-bilang. The script was used as a means of secret communication with her followers in opposing and against the Dutch. Mastering government and finance administration (based on experience in the Kingdom of Tanete) and leadership (being the Queen in Pancana and Lamuru). Another thing that can be mentioned is its ability to master the language (Malay, Bugis, Makassarese and Arabic). Like two sides of a coin, both fighting spirit and intellectual power could be all found in Colliq Pujie herself [9]. There was also a strong female figure in leading the country named Besse Kajuara. During Besse Kajuara's government reign, such tension between Bone and the Dutch Company reoccurred. The pressure of the Dutch Company always outlined to renew the so-called Bungaya agreement. But Besse Kajuara firmly refused to renew the agreement [10].

In the adaptation of Colliq Pujie's work on the voyage of Sawerigading to all directions. In the story of La Galigo, Sawerigading was well known as an extraordinary figure and had 
extraordinary strength. On his voyage, he toured several islands and even reached China. Years later, it is said he had a child named We Tenri Dio who settled in Selayar, who first built the Putabangung kingdom (We Tenri Dio's Funeral Complex Inscription). It is reported that We Tenri Dio is Sawerigading's second child from his wife named We Cudai. Since we were in the womb, We Tenri Dio had shown signs of a leader. Since birth, she had been even appointed as bissu with the title of Batari Bissu with such nickname as Bissu Lolo (Young Bissu) [11].

The data have become an empirical evidence of how significant the roles of women in the past as mentioned in the manuscript. The position of women appeared as active participants who were fully involved in historical events. The figures such Colliq Pujie and Besse Kajuara were both Buginese female leaders who opposed the Dutch with their respective strategies. They did not only play a role in defending their territory. Similarly, there was a figure of an age-old woman named Cleopatra in Egypt. At that time, the Roman empire was very ambitious to take control Egypt. Cleopatra, the queen of Egypt, tried all ways as she could way to protect Egypt from Roman rule until the end of her life [12].

Female figures such as Cleopatra, actually has been recorded in local manuscripts (lontaraq), but have not been published massively. A number of Buginese-Makassarese female figures played a role in the political, economic and knowledge arena. In Gowa for example, the form of government declaring a social-political contract between the people and the king was invoked by a woman called (Tomanurung) in the kingdom of Gowa. Women played a role in building and establishing their own kingdom as recorded in Lontaraq notes. They were also known as leaders and established the kingdoms, We Tenri Dio was one of them. The data were continuously obtained on female leaders who had been the state leaders within the Buginese-Makassarese kingdom. They were open-minded and considerably brave in the world of politics and power, a rebel, and a queen in two kingdoms namely Luwu and Tanete. Matthes also acknowledged the intelligence, courage and open-mindedness of Buginese-Makassarese women. Such brave figure could be found, for example, in Petta Pacu, Besse Kajuara, an experienced politician, Datu Lagusi, who taught Matthes about Buginese literature [6].

Actually, one that influenced women into the domestic area, when referring to the reproductive function of women, triggering women did not have much time to play a role in the public sector, as their obligations is to take care of children. Taking care of the household becomes their primary obligation [13]. This happened to Darmasiah and Sitti Saerah, who were very respectful and obedient to their husbands, the survival of women relied on their husbands. Husband as a determinant of their life survival. The second strand of this story showed that women only played a domestic level. Yet, analyzing their life till the ending, that these two women had an important role to their husband. Their husband's success and safety depend on their wife's prayer. Also, the capacity of the religious knowledge of these two figures had shifted their position to not only working in the domestic sphere, but also in the public sphere as Islamic scholars.

\section{Conclusion}

To conclude, the roles of Buginese-Makassaris women in both public and domestic areas had been taking place since centuries ago. Based on data from the BugiseseMakassarese manuscripts, it has been recorded a number of female figures who have inspired women today. As noted in La Galigo, the important role of Sang Hyang Seri in the life of 
humanity on this earth, and We Tenri Dio, the daughter of Sawerigading who founded and led the kingdom of Puta Bangun in Selayar. In addition to La Galigo, there is also a Buginese-Makassarese manuscript that tells the story a woman named Rabiatul Adawiyah, a strong woman who received inspiration from God, to become an expert on worship and a female guardian and Sufi. Similarlt, Sitti Saerah and Darmasiah are such female figures working in the domestic area at the beginning, but due to the capacity of religious knowledge, they eventually became a scholar and place of seeking for knowledge.

Following this, not only religious female experts are told. But, the story of some Buginese-Makassarese women as warrior figures, intellectuals, political figures are also told, such as Colliq Pujie and Besse Kajuara. They were scholars, accomplished politicians, and brave persons who had a high level of struggle. Thus, it is reasonable to say that some discussions about gender equality demanding equality have long been occurring within Buginese-Makassarese life. Such changes of roles were triggered by political factors of the Dutch East Indies, saying that women in the past time should just stay home as a strategy of discouraging women's resistance towards their colonization.

\section{References}

[1] K. H. H. Muhammad, Islam Agama Ramah Perempuan: Pembelaan Kiai Pesantren. Yogyakarta: Fahmina Institute : LKiS, 2004.

[2] J. Burhanuddin, Ulama Perempuan Indonesia. Jakarta: Penerbit PT Gramedia Pustaka Utama bekerja sama dengan PPIM IAIN Jakarta, 2002.

[3] M. R. Tang, M. P. N. (Jakarta), and S. I. P. Nusantara, Meong Palo Bolonge: Sebuah Puisi Lirik Sastra Bugis Klasik Episode Galigo : Telaah Struktur dan Simbol Budaya Lama Manusia Bugis. Jakarta: Masyarakat Pernaskahan Nusantara, 1998.

[4] NN, "Lontaraq Sukkuna Wajo."

[5] N. Rahman., "Hikayat Sitti,” Makassar, 1991.

[6] N. Rahman., Retna Kencana Colliq Pujie Arung Pancana Toa, 1812-1876: Intelektual Penggerak Zaman. Makassar: La Galigo, 2008.

[7] C. Macknight and M. Hadrawi, "Festival Budaya dan Seminar Internasional La Galigo III, 17 to 23 December 2018, Watansoppeng, Sulawesi Selatan, Indonesia,” Archipel, pp. 3-7, 2019.

[8] F. A. E., Ritumpanna Walenrennge: Sebuah Episoda Sastra Bugis Klasik Galigo. Jakarta: Ecole francais d'Extrame-Orient: Fakultas Sastra Universitas Indonesia: Yayasan Obor Indonesia, 1999.

[9] S. utami Dewi, "Colliq Pujie: Perempuan Cerdas Unik dan Perkasa dari Bugis," Makassar, 2009.

[10] H. R. Djibe, A. S. Makuradde, and Mantasia., Besse Kajuara, Srikandi Tangguh dari Timur, Ratu Bone XXVIII. Makassar: Media Fajar, 2007.

[11] N. Ram and A. B. T. Bandung, I La Galigo. Makassar: Pustaka Refleksi, 2011.

[12] E. D. S. Bradford, Cleopatra. London; New York: Penguin Books, 2000.

[13] D.- Dwikurniarini, "Peranan Perempuan di Luar Rumah Tangga dalam Perspektif Historis," Mozaik J. Ilmu-Ilmu Sos. dan Hum., 2015. 